\title{
A PROPOSAL ABOUT THE ORIGIN OF THE INDO-EUROPEAN LOCATIVE PLURAL
}

One of the most significant recent developments in the field of historical linguistics has been the identification of what Fox (1995: 194) calls "laws' of language development"-a methodology "for determining which changes are more likely than others, and ... criteria for determining the overall direction of linguistic change." This methodology is largely an aspect of what has come to be known as "grammaticalization theory," which, according to Heine (2003: 575), is really "neither a theory of language nor of language change; its goal is to describe grammaticalization, that is, the way grammatical forms arise and develop through space and time, and to explain why they are structured the way they are." The process of grammaticalization "is hypothesized to be essentially unidirectional" (Heine 2003: 575) and therefore potentially "offers an explanatory account of how and why grammatical categories arise and develop" (Heine 2003: 578). Such explanation serves as "a potentially powerful adjunct to the methods of reconstruction, especially on an internal basis" (Fox 1995: 206), since it leads the historical linguist to principled conclusions about the structural sources of both attested and comparatively reconstructed morphosyntactic patterns. In this brief paper I wish to apply one such "law' of language development" to account for the origin of the traditionally reconstructed Indo-European locative plural suffixes * ${ }^{*}-s i$ (Gk. -si) and ${ }^{*}-s u$ (Skt. su, OCS - xz) (cf. Szemerényi 1996: 165). Like Fox (1995: 206), I acknowledge that the application of this methodology can be "speculative and controversial"; however, I offer my proposal as a reasonable possibility for developments within Indo-European.

Before I proceed in presenting the main lines of my argument, I must contextualize it within my general views of the nature and evolution of Indo-European itself. For many years now I have espoused what Adrados (1992: 1) has called the "new image" of Indo-European morpho-syntax. This theoretical orientation holds that such inflectional categories as number and case developed only gradually within Indo-European and the early dialects and that the rich inflectional system associated with such dialects as Sanskrit and Greek is an artifact of evolution within these dialects, not within Indo-European itself. Support for the "new image" viewpoint can be found, for example, in Adrados (1985, 1987), Erhart (1970, 1993), Lehmann (1974, 1993), and Shields (1982a, 1982b, 1983, 1985, 1987, 1991a, 1991b, $1992,1993,1994,1995,1999,2000$ a , 2000b). Since, according to the "new image," a non-singular category emerged only at the end of the common Indo-European period, dialectal variation in the form of non-singular suffixes, including the locative plural, is frequent. Some attested case endings, like the Hittite genitive affixes 
-an and $-a \check{s}$, themselves manifest variability in number assignment (cf. Shields 2000b: 147). Moreover, the late emergence of the so-called adverbial cases (i.e., "instrumental, dative, ablative, locative, and the genitive in some uses" [Lehmann 1958: 182]) also accounts for formal and functional differences between dialects as new case categories were created from the bifurcation of still earlier, functionally broader categories. For what follows, it is important to note that even more traditional Indo-Europeanists like Beekes (1995: 173) acknowledge that "the dative and the locative were probably in origin one case." Kurylowicz (1964: 189-196) presents an especially detailed and coherent argument in support of the original identity of these two cases. He emphasizes that the function of the original "locative" case involved not only the specification of where but also of whither (placing it in competition with the so-called accusative of goal); "the dat. is genetically nothing else than an offshoot of the loc. used with personal nouns"; thus, for example, to the man and to the city share the common denotation "goal" (Kurylowicz 1964: 190, 195). More recently, Meier-Brügger (2003: 272) similarly asserts that "depending in turn on the nature of the verbal action, the [Indo-European] locative may have the function of indicating the goal of a movement that is coming to completion." According to Universal 158 of the WEB-based Universals Archive of the University of Konstanz, any marker of both the dative and locative functions "also occurs as an allative marker," "presumably, ... reflect[ing] a sequence of grammaticalizations: a locative is first grammaticalized as allative, then as dative."

The allative role of the Indo-European locative is important typologically since, according to Svorou (1994: 78, qtd. in Heine 1997: 45), it is common for "the bodypart noun for 'eye' [to] develop into an allative marker ('to, toward')," as in the case of Papago (a Uto-Aztecan language) wui 'eye' (Heine 1997: 45). ${ }^{1}$ Svorou (1994: 78) observes: "We could explain this development, if we accept the following: eyesight, in a naïve view, emanates from within the human body, and is directed towards the outside world. The eyes, as the organ of vision, may be metonymically used for eyesight. In fact, phrases such as 'She could see no living soul as far as her eyes could reach' are not uncommon. Thus, the conceived directedness of eyesight makes the eye terms eligible as lexical sources of directional grams." Heine (1997: 37) cites Yucatec, a Mexican Mayan language, as an example of a lect where the grammaticalized body-part word eye (ich) has subsequently broadened its meaning to include a static locational sense 'in, inside.'

\footnotetext{
${ }^{1}$ Although it is well established that words for body-parts commonly come to serve as exponents for spatial orientation and then evolve into fully grammaticalized locational affixes (Heine 1997: 35-65), environmental landmarks (e.g., 'earth,' 'sky,' 'mountain,' etc.) can undergo the same development (Heine 1997: 38), although they are "less important than body-parts as a source for ... spatial concepts." Even more rarely "the sources for spatial points of orientation may include dynamic concepts typically expressed by motion verbs like 'come,' 'go,' 'follow,' 'precede,' 'pass,' and 'descend,' or by verbs of static location such as 'remain,' 'stay,' 'sit,' and the like" (Heine 1997: 39).
} 
When a lexical item such as 'eye' is grammaticalized as a case suffix, it becomes subject to "a quantitative ('syntagmatic') reduction: forms become shorter as the phonemes that comprise them erode" (Hopper \& Traugott 1993: 145-146). Hopper \& Traugott (1993: 145) explain: "The fusion of a lexical item and a clitic as stem and affix that typifies morphologization is accompanied by phonological changes of various sorts. Most often these changes are characterizable as reductions: vowels and consonants are dropped, stress or tone accent is lost causing an accentual readjustment over the newly formed word, and adjacent phonological segments are assimilated to one another." Heine \& Reh (1984: 21) use the term erosion as a general descriptor to characterize a range of possible "reductions" in the process of grammaticalization. They point out that a common type of erosion is the "syllabic" variety, whereby polysyllabic morphemes undergoing grammaticalization tend to become monosyllabic. Both initial and final segments (those at word peripheries) are the most susceptible to such erosion (Heine \& Reh 1984: 23).

In my view, the Indo-European lexical item 'eye' which underwent grammaticalization as a locative plural suffix was ${ }^{*} o k^{w} s i$, attested in Sanskrit $a k s s i$ as a heteroclitic neuter $i-/ n$-stem, i.e., ákși, akșnás (cf. Mallory \& Adams 1997: 188). Of course, the antiquity of this attestation of the root ${ }^{*} o k^{w}$ - has been questioned, especially by Beekes (1987). To this end, he points out the paucity of attested $i-/ n$ stem neuters, especially their absence in Hittite, which extensively preserves heteroclitic $r-n$-stem nouns; and he explains the extant Sanskrit examples as resulting from the addition of $-i$ or laryngeal to nominative forms, although he does admit that ákși itself "probably was the original inflection"-"the structure of the word is totally unclear, other languages pointing to simple ${ }^{*} H_{o k} k^{w_{-} "}$ (1987: 55). "It has been assumed," Beekes (1987: 55) states, "that the $-i$ originated from the (frequent) dual ákși." However, he notes that if the latter were true, one "would expect a complete $i$-inflection ..., but this is not impossible. On the other hand, a form in $-H$ cannot be ruled out either" in his opinion (1987: 55). However, I would emphasize that heteroclitic declension of any kind has the potential to be genuine archaism (cf. Misra 1968: 59-60, Burrow 1973: 248) and that Benveniste's theory (1935: 75ff.) of significant transference of $i-(/ n$ - $)$ stem neuters to the masculine-feminine $i$-stem class, while not absolutely verifiable, remains a reasonable explanatory statement. Moreover, the fact that Old Church Slavic attests the form for 'eye' as an $s$-stem (oko) implies the presence of an original s-element in this item; and "as demonstrated by OHG awi-zoraht, au-zoraht beside auga-zor(a)ht openly, there was beside Gmc. *augan- a stem *awi- < ${ }^{*} a g w i$, PIE $o k^{w} i$ " (Lehmann 1986: 48) which independently implies the presence of an original ${ }^{*} i$ in the word.

It is possible then that Indo-European created a general locative formation by grammaticalizing the word ${ }^{*} o k^{w}{ }_{s i}$ 'eye' in accordance with "laws' of language development." In the process of grammaticalization, syllabic erosion took place, reducing the morpheme to ${ }^{*} s i$, still attested in Greek. Gamkrelidze \& Ivanov (1995: $335)$ maintain that ${ }^{*}$-si represents the locative marker ${ }^{*} i$ following the plural marker ${ }^{*}$ $s$ (cf., e.g., Gk. pód-es, Lat. ped-ès 'feet'). I would propose that this morphological 
analysis of $*_{-s i}\left(<{ }^{*} k^{w} s i\right)$ was actually implemented by late Indo-European speakers as part of a morphological reinterpretation of the original grammaticalized and eroded ${ }^{*} o k^{\mathrm{w}} s i$. Once ${ }_{-i}$ was identified with the locative/deictic marker ${ }^{*} i$ of the singular (cf., e.g., Skt. pád-i, Gk. pod-i 'foot'), this locative/deictic element, following the now "plural" suffix ${ }^{*}-s$, was subject to substitution by other functionally equivalent locative/deictic particles-namely, ${ }^{*} u$ (cf. Hirt 1927: 11) and also * $e$ (cf. Hirt 1927: 10-11). ${ }^{2}$ *-su (Skt. -su, OCS - xb) results from the substitution of the first morpheme and *-se (Lith. -se, cf. tévo-se 'fathers,' cf. Endzelins 1971: 137) from the substitution of the second. The fact that "in the older Vedic poems ... the locative -su [is] treated for purposes of sandhi (juncture) like [a] distinct word rather than [an] inflectional element" (Lehmann 1993: 151) lends credence to the notion that its origin may ultimately be traced to the grammaticalization of an independent lexical item.

In conclusion, I do not wish to assert here that the theory just presented is the only way to analyze the attested linguistic data historically. However, I feel quite comfortable in stating that this theory is consistent with contemporary notions of the nature of linguistic change and should therefore be given consideration as a possible explanatory statement. Only with additional refinements in our models of linguistic change can this theory ultimately be confirmed or rejected. ${ }^{3}$

\footnotetext{
${ }^{2}$ The $o$-stem locative plural derives from *-oi-su (cf., e.g., Skt. -esu, Gk. -oisi), with *oi-constituting the stem vowel plus the non-singular marker *-i (cf., e.g., nom. pl. Gk. lúko-i, Lat. lup-i 'wolves,' cf. Shields 1992: 67). If the Hittite dative plural suffix -aš indeed represents *-o-su "with apocope of the final vowel" (Sihler 1995: 253 ), then ${ }^{*}$-oi- most certainly would constitute a later hypercharacterization of the plurality of the ${ }^{*}-s u$ suffix, perhaps suggesting the validity of my contention that the ${ }_{-s-}$ of $*_{-s-u}$ originally had nothing to do with plurality.

${ }^{3}$ In Shields (2001) I show, using current principles of grammaticalization theory, that the Indo-European first person singular verbal desinence ${ }^{*}-m$ can be derived from the first person nominative singular personal pronoun *eg(h)om. Of course, the validity of this analysis is subject to the same stipulation.
} 
References

ADRADOS, Francisco. 1985. "Der Ursprung der grammatischen Kategorien des Indoeuropäischen." In: Grammatische Kategorien: Funktion und Geschichte, eds. B. Schlerath \& V. Rittner, 1-46. Wiesbaden: Ludwig Reichert.

. 1987. "Binary and Multiple Oppositions in the History of Indo-European." In: Festschrift for Henry Hoenigswald, eds. G. Cardona \& N. Zide, 1-10. Tübingen: Gunter Narr.

1992. "The New Image of Indoeuropean: The History of a Revolution." Indogermanische Forschungen 97: 1-28.

BEEKES, Robert S. P. 1987. "Indo-European Neuters in -i." In: Festschrift for Henry Hoenigswald, eds. G. Cardona \& N. Zide, 45-56. Tübingen: Gunter Narr. 1995. Comparative Indo-European Linguistics: An Introduction. Amsterdam: Benjamins.

BENVENISTE, Emile. 1935. Origines de la formation des noms en indo-européen. Paris: Maisonneuve.

BurRow, T. 1973. The Sanskrit Language. Rev. ed. London: Faber \& Faber.

ENDzelins, J. 1971. Comparative Phonology and Morphology of the Baltic Languages, trans. W. Schmalstieg \& B. Jëgers. The Hague: Mouton.

ERHART, Adolf. 1970. Studien zur indoeuropäischen Morphologie. Brno: Opera Universitatis Purkynianae Brunensis Facultas Philosophica. 1993. Die indogermanische Nominalflexion und ihre Genese. Innsbruck: Institut für Sprachwissenschaft der Universität Innsbruck.

Fox, Anthony. 1995. Linguistic Reconstruction: An Introduction to Theory and Method. Oxford: Oxford UP.

GAMKRELIDZE, Thomas \& Vjačeslav Ivanov. 1995. Indo-European and Indo-Europeans, trans. J. Nichols. 2 vols. Berlin: de Gruyter.

HenNe, Bernd. 1997. Cognitive Foundations of Grammar. Oxford: Oxford UP. . 2003. "Grammaticalization." In: The Handbook of Historical Linguistics, eds. B. Joseph \& R. Janda, 575 601. Malden, MA: Blackwell.

HEINE, Bernd \& Mechthild Reh. 1984. Grammaticalization and Reanalysis in African Languages. Hamburg: Helmut Buske.

HrRT, Hermann. 1927. Indogermanische Grammatik. Vol. 3. Heidelberg: Winter.

HopPer, Paul \& Elizabeth Closs Traugott. 1993. Grammaticalization. Cambridge: Cambridge UP.

KURYLOWICZ, Jerzy. 1964. The Inflectional Categories of Indo-European. Heidelberg: Winter.

LEHMANN, Winfred. 1958. "On the Earlier Stages of the Indo-European Nominal Inflection." Language 34: 179-202.

1974. Proto-Indo-European Syntax. Austin: U of Texas P.

1986. A Gothic Etymological Dictionary. Leiden: Brill.

1993. Theoretical Bases of Indo-European Linguistics. London: Routledge.

Mallory, J. P. \& D. Q. Adams, eds. 1997. Encyclopedia of Indo-European Culture. London: Fitzroy Dearborn.

MEIRER-BRÜGGER, Michael. 2003. Indo-European Linguistics. Berlin: de Gruyter.

Misra, Satya. 1968. A Comparative Grammar of Sanskrit, Greek, and Hittite. Calcutta: World Press Private.

SHIELDS, Kenneth. 1982a. Indo-European Noun Inflection: A Developmental History. University Park: Penn State P. . 1982b. "The Indo-European Origins of the Old Hittite Directive Case." Journal of Indo-European

Studies 10: 273-282.

1983. "Hittite Pronominal Suffixes in -l." Indogermanische Forschungen 88: 191-201.

1985. "Gothic meina and Related Germanic Forms." Michigan Germanic Studies 11: 62-70.

1987. "Some Remarks about the Dual of Indo-European o-Stems." Journal of Indo-European

Studies 15: 341-352.

. 1991a. "Comments about the o-Stem Genitive of Indo-European." Historische Sprachforschung 104: 52-62.

1991b. "Speculations about the Early Indo-European Genitive-Ablative and Dative-Locative."

Linguistique Balkanique 34/1-2: 21-27.

1992. A History of Indo-European Verb Morphology. Amsterdam: Benjamins.

1993. "The Origin of the Armenian Locative Plural." Journal of Indo-European Studies 21: 55-62.

1994. "On the Origin of the Hittite Accusative Plural Suffix -uš." Hethitica 12: 79-85.

1995. "On the Origin of the Indo-European Feminine Gender Category." Indogermanische Forschungen 100: 101-108.

1999. "Sanskrit Dative Singular -āya and Its Indo-European Connections." Historische Sprach-

forschung 112: 26-31. 
2000a. "Germanic Dative Personal Pronouns in *-s." Folia Linguistica Historica 20: 25-35.

2000b. "Indo-European o-Stem Genitives in *-i." Lingua Posnaniensis 42: 145-150.

2001. "A Note on the Pronominal Origin of the Indo-European First Person Singular Verbal Desinence." Word 52: 257-262.

SIHLER, Andrew. 1995. New Comparative Grammar of Greek and Latin. New York: Oxford UP.

Svorou, Soteria. 1994. The Grammar of Space. Amsterdam: Benjamins.

SZEMERENYY, Oswald. 1996. Introduction to Indo-European Linguistics. 4th ed. Oxford: Clarendon P.

UnIVersais ARChIVE. Ed. F. Plank. 17 June 2003. Fachbereich Sprachwissenschaft, Universität Konstanz. 2

June 2004 <http://ling.uni-konstanz.de/pages/proj/ sprachbau.htm>.

\section{Povzetek}

\section{NOVA DOMNEVA O IZVORU INDOEVROPSKEGA MESTNIKA MNOŽINE}

C̆lanek izvaja inđoevropsko sklonilo za mestnik množine -si iz indoevropske besede za oko, ki tudi sicer po jezikih pogosto označuje smer gibanja, posledično tudi prostorskost sploh. Avtor dokazuje, da je oblika indoevropske besede 'oko' s formantom -s- stara. Beseda ok ${ }^{\mathrm{W}}$ si, dodana kaki samostalniški osnovi, naj bi se bila obrusila $v$-si, slednji naj bi se drugotno tolmačil kot množinski -s- + sklonilo -i mestnika ednine, ta i pa se je v množini mestoma nadomeščal $\mathrm{z} u$ ali e. 